\title{
Erratum: Background perspectives on infinity and God
}

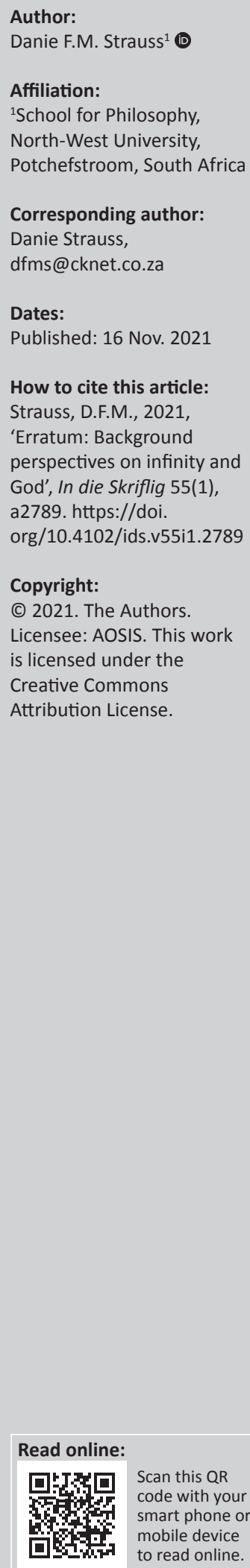

In the published article, Strauss, D.F.M., 2019, 'Background perspectives on infinity and God', In die Skriflig 53(1), a2421. https://doi.org/10.4102/ids.v53i1.2421, there was an error in the affiliation. Instead of 'Department Philosophy, University of the Free State, Bloemfontein, South Africa', it should be 'School for Philosophy, North-West University, Potchefstroom, South Africa'.

This correction does not alter the study's findings of significance or overall interpretation of the study results. The publisher apologises for any inconvenience caused. 


\section{Background perspectives on infinity and God}

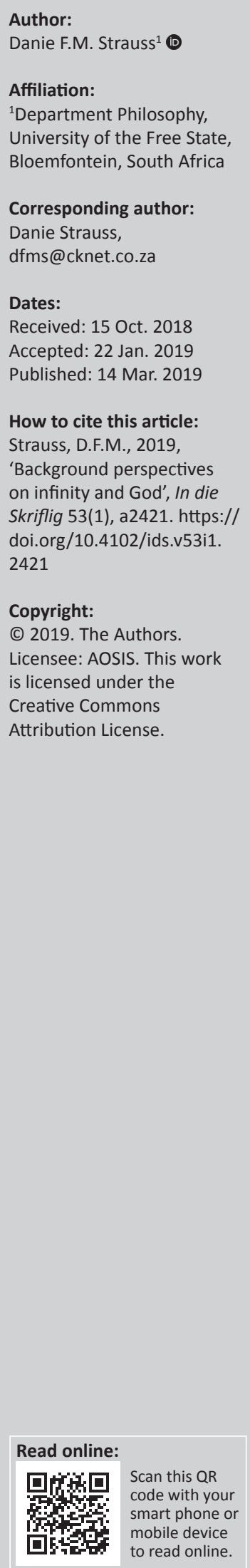

Initially the connection between divinity and infinity was accompanied by an initial notion of infinity in the literal sense of one, another one, and so on - without an end, endless. Via Anaxagoras we reach Aristotle for whom it would be contradictory to hold that God is infinite, because the unlimited nature of infinity cannot be reconciled with the fullness of being of perfect reason. After Origen it was Gregor von Nyssa who positively affirmed that infinity belongs to the essence of God. Augustine was also more explicit in his view of infinity, because, according to him, the set of 'all finite integers' could be comprehended at once as an actualinfinite totality. An element of the thinking of Thomas Aquinas acknowledges that God's infinity could be known, albeit in an inadequate manner. Aquinas continues key elements of the Greek-Medieval tradition, for according to him, in eternity there is no succession, because it exists totally at once. Cusanus took God as the actual infinite to be the coincidentia oppositorum. Descartes defends the view that the infinite, which is God, is known before the finite. Kant aptly introduces the expression 'successive infinite' but rejects the idea of an infinite totality. After Kant Maimon distinguishes between the human mind and a divine mind associated with succession and at once respectively. Hegel grasped the distinction between ordinal and cardinal numbers. Bolzano, Weierstrass, Dedekind and Cantor explored the at once infinite mathematically. Finally, what has been explained thus far sheds light on the struggle of theologians with the assumption that infinity is actually a theological notion (God's infinity) transferred to mathematics.

\section{Greek roots}

Ever since the idea of infinity entered Greek philosophy, it harboured an ambiguity. On the one hand, it was introduced in pre-Socratic philosophy to designate the arche [Origin] of the cosmos, but, on the other hand, it eventually was de-divinised. Anaximander chose the apeiron as his principle of origin, the unbounded-infinite. Diels and Kranz translate apeiron as the limitlessindeterminable (grenzenlos-Unbestimmbare) (Diels \& Kranz 1960 B. Fragment 1; see also Solmsen 1962:113). An extensive analysis of the secondary literature is found in Sweeney (1972:1-54) before he proceeds with his own assessment of the thought of Anaximander. Sweeny points out that mathematical connotations soon emerged alongside reflections about origins. The primary mathematical understanding of the infinite is given in the basic awareness of the succession of one, another one, yet another one - and so on indefinitely, infinitely.

\section{Introducing the infinitely small}

In the Eleatic school of Parmenides and the thought of Anaxagoras, the second mathematical meaning of infinity surfaced - the infinitely small (see Solmsen 1962:114).

The fact that the Pythagoreans proceeded from the thesis that everything is number, should not be interpreted as if they explored arithmetic or geometry in a strict sense. Philip points out that the situation is rather mixed. The term mathematics is 'not to be taken in a strict sense as arithmetic or geometry but rather as number speculation, arithmology or even, number mysticism' (quoted by Sweeney 1972:85). Eventually both the notions of unity and infinity played a key role in the affirmation of God's infinity. In passing, it should also be pointed out that, while for the Greeks numbers were 'things with which one can count', the modern conception holds that numbers 'are things with which one can calculate' (Hasse \& Scholtz 1928:30).

Anaxagoras expressed crucial elements of this switch (Diels \& Kranz 1959-1960 B. Fragment 8) by affirming that whatever there is in the world order is not separated as if chopped off with an axe. These developments should also be related to the way in which Parmenides used spatial features in his metaphysics of being (cf. Diels \& Kranz 1959-1960 B. Fragment 8:3-6). One of his followers, Zeno (known for his paradoxes), explored the spatial whole-parts relation in his B. Fragment 3. This relation entails the infinite in its second meaning, focused in the infinitely small, but 
Anaximander was unaware of the views of the Eleatics (Sweeney 1972:58).

Under the influence of Xenophanes' idea of God, we find that Anaxagoras shifted the emphasis to the nous, for he was the first who positioned the nous as ruler over matter. According to Anaxagoras, the nous is not determined by any limits, it is not intermingled with germs of matter and it alone is selfsufficient - for itself (Diels \& Kranz 1959-1960 B. Fragment 12). In B. Fragment 14, Anaxagoras employs 'divinity' terms by characterising the nous as eternal.

This does not alter the fact that in Xenophanes' idea of God, at least, the form motive has been dissociated from the principle of matter. In this regard, he is doubtless the precursor of Parmenides, although he prepared the way even more for Anaxagoras' doctrine of nous.

\section{De-divinising matter}

According to Anaxagoras, the nous can only know something if it does not participate in it and rule over it. This embodies an epistemological articulation of the primacy of the form motive in Greek philosophy, accompanied by the dedivinisation of the rigid, motionless and disorderly mattergerms - as a continuous mixture of everything with everything. Only the nous is called divine - in opposition to all the rest - as it appears from the Testimonia 48 and 49. According to Diogenes (2.6) all 'things were together' until Nous [mind] came and 'set them in order' (quoted by Guthrie 1980:272-273). This entails that there is a portion of Mind in living things animating (controlling) them. Guthrie (1980:279) continues: 'It is nowhere in the extant fragments called God, but this may be accidental' for 'it is impossible that Anaxagoras should not have thought of it as divine ( $\theta \varepsilon i \tilde{o v})$. '

There is an element of continuity with Anaxagoras in the thought of Socrates, because both assign to the nous the task of being the form-giver of the cosmos. This returns in Plato's dialogue Timaeus, for the form motive is at once seen as the origin of the good and beauty in the cosmos. All knowledge is directed towards the good and the beauty.

Plato distinguishes between the transcendent realm of eternal, static ontic forms and the sensory world of becoming and change. If everything is subject to change though, then knowledge would be impossible. The moment one attempts to obtain knowledge, it already changed into something different (Cratylus 439e-440a).

\section{The essential being of things in a world of change}

Probably with this in mind, Aristotle mentions that, already in his youth, Plato did get acquainted with the doctrines of Heraclitus according to which all perceivable (sensory) things prevail in a state of flux so that no knowledge of them is possible (Metaph. 987a, 30). The problem unveiled here by
Plato, namely that between knowledge, making an appeal to constancy and the things known being in a state of continuing change, a basic problem that even today still needs elucidation from any critical theory of science is highlighted. Plato explained this state of affairs with his theory of ideas that has already at the end of the dialogue, Cratylus, revealed a tendency to become more rigid, for even the good and beauty were related to their static eide.

Because the eide in the final analysis entail a metaphysical duplication of the world of the senses, the question arises: What is the origin of the diversity of eidē? Eventually the focus of Plato's argumentation on the idea of the good, which exhibits an elevated power and dignity while providing knowability to the objects of knowledge, is particularly important. Krämer (1969:29-30) aptly remarks: 'The closing section of Book 6 of Politeia, to be more precise, the section 508 D-509 B, concerns the acknowledged most important part of his entire dialogical work.' The description of the idea of the good apparently contradicts Politeia 526e and 532c where the highest being seems to be related to the good. In any case, it is not possible to deduce from this that the idea of the good is the highest eidos among the eide.

Nonetheless, the question returns: Is the idea of the good the god-head for Plato? Even if one argues that all the properties, which the idea of the good possesses are possessed by the god-head for Plato, it still does not follow that it does not show that Plato indeed identified both. For Plato, God is immaterial and spiritual and stands above the gods. Plato does call God explicitly good (Politeia 379b; $380 \mathrm{~b})$, but this does not mean that he holds that the good is God.

\section{The divine workmaster (demiourgos)}

The demiurg in Politeia is related to the demiurg of Timaeus where it receives the role of form-giver (cf. Timaeus 28a, 6). In Politeia 507 c, 7, Plato speaks of the maker (demiourgos) of our senses and in 530a, 6 of the maker of the heavens. Later on it is argued that the maker (demiourgos) of tables and beds produce both types of objects by keeping the idea (idean) of each in mind although the ideas themselves are not produced by any human demiurg. Nonetheless, there is a craftsman who has made everything that the other craftsmen each made separately. He, however, does not only make all articles of daily use, but also everything that originate from the earth - even the earth, the heaven, the gods and everything existing in the heaven and underneath the earth (596b, 6-c, 9). Subsequently, it is explained that it is indeed God (theos) who has made all things according to their essential nature (eidos) (597c and d). The eidos, according to which the human craftsman makes a bed itself, is produced by the divine workman.

Yet, matter remains formless, testifying to a dualistic understanding of the universe. If there is an eidos for everything in the world of becoming, it is impossible to have a form for the formless! 


\section{The primordial opposition of pure matter and pure form}

The thought of Aristotle is caught up in a similar dualism between matter and form. According to Happ (1971), the 'MatterForm relation ... is ultimately based in a Primordial Relation (Ur-Relation) "matter in itself" (pure matter): "pure form:"'

Die Hyle-Form-Relation entstehen nicht gleichwertig nebeneinander, sondern bilden im großen und ganzen eine Rangfolge. Sie verweisen also auch nicht zu ihrerBegründung stets auf eine andere Hyle-Form-Relation und so fort ins Unendliche (infinite Regre $\beta)$, sondern gründen letztlich alle in einer Ur-Relation 'Hyle an sich (reine Hyle)': 'reine Form' ... (p. 799)

According to Aristotle, we have to distinguish between the potential and the actual infinite (Phys. 204a, 20ff.; Metaf. 1066b, 11ff.). However, he rejects the latter on two grounds: firstly, if the actual infinite has parts, they must actually be also infinite, but this would entail the absurdity that the whole is not any longer larger than a part. Secondly, if the parts are finite, the impossibility would hold that the actually infinite could be counted. Alternatively, there must be transfinite cardinal numbers that are neither even, nor uneven. Therefore, Aristotle concludes that only the potential infinite exists, albeit as something imperfect.

Moreover, Aristotle accepts only concrete material extension and every material thing occupies a place - from which it follows that the cosmos must be finite. In the absence of a body, there is no subject to which the predicate 'place' could be applied. The modern abstract mathematical concept of an empty space is not known to Aristotle. The lasting influence of this view is still found in the thought of Descartes. According to him, the essential characteristic of a material body is given in extension: 'the nature of body consists not in weight, hardness, colour and the like, but in extension alone' (Principles IV; Descartes 1965b:200). He holds that a vacuum does not exist, 'that is, a space in which there is no substance', because 'the extension of space or internal place is not different from that of body' (Principles XVI; Descartes 1965b:207 - see also Von Weizsäcker 1972:58ff.).

\section{Aristotle: noēsis noēseōs, thought thinking itself}

For Aristotle, the idea of God entails that 'He is the absolute, actualized, perfect Reason, whose thinking has only itself as its object (the noēsis noēseōs, 'thought thinking itself')' (see Dooyeweerd 2013:71). Also look at a similar characterisation by Dooyeweerd (2013:268) which reads: 'For Aristotle, the deity is the "noēsis tes noēseōs," pure thought, which has only itself, as the fullness of all true being and living, for its object, in blissful contemplation.' Mühlenberg (1966:166) summarises the position of God in the Aristotelian philosophy in a similar fashion: 'Desewegen ist in der aristotelischen philosophie Gott die Spitze einer hierarchisch gedachten Vollkommenheitsordnung.' [Therefore, within the philosophy of Aristotle God is at the top of a hierarchically contemplated perfect ordering].
This view would obstruct any attempt to attribute infinity to God, because the unlimited nature of infinity cannot be reconciled with the fullness of being of perfect reason. This same legacy prompted Origen to hold, in his work on 'The Principles' ( $\pi \varepsilon \rho i \dot{\alpha} \rho \chi \tilde{\omega} v)$ that if the power of God was infinite (apeiron), God would not be able to know himself. The modern founder of the mathematical theory of transfinite numbers, George Cantor (1962:403), refers to this view of Origin in his Gesammelte Abhandlungen. The neo-Platonistic thinker, Plotinus, reconquered lost territory by applying the term apeiron both to matter as permanent substratum and to the One (as form-giving Origin). However, the developments within Greek philosophy is not at ease with the identification of perfection and infinity.

\section{The matter and the One in the neo-Platonism of Plotinus}

Within the neo-Platonism of Plotinus the Greek dialectic of matter and form returns in the opposition of matter and the One (Enneads II, 4, 4, 8; cf. II, 4, 6, 4 and 19). The same applies to the opposition of light and darkness which are respectively identified with the One and matter (En. VI, 8, 18). In order to break through the identification of matter in the sense of formlessness and infinity, subsequent thinkers had to reintroduce infinity as a property of God. This was done by criticising Aristotle's logic which opened up the possibility to attribute infinity to God. Mühlenberg (1966:165) appreciates as the actual merit of Gregor von Nyssa that he explored an endlessness that ascends to the infinity of God and it was Gregor von Nyssa who viewed infinity as belonging to the essence of God (p. 169).

Augustine is more explicit in his appreciation of the actual infinite. Here, Cantor (1962:402) also points out that he (Augustine) views the set of 'all finite integers' as something that God can comprehend at once as an actual-infinite totality 'als ein actual-unendliches Ganzes, als ein Transfinitum' [as an actual-infinite totality, as a Transfinite].

\section{From Thomas and Cusanus to Descartes}

The stage was now set for the medieval era up to Thomas Aquinas. What is knowable to the highest degree is solely the infinity of God which is pure and not mixed with any matter. Only 'bad' infinity (Aristotle's potential infinite) cannot be known, whereas God's infinity could be known, albeit in an inadequate manner owing to the weakness of the human being (Cohn 1960 [1896]:69-70). All perfection rests on the formal side of being. The unboundedness of matter is therefore imperfect, because it lacks form. 'The unlimited form however, that is God, is perfect since it lacks any limiting matter' (Cohn 1960 [1896]:70).

During the medieval period, an important distinction was made between time and eternity. Thomas Aquinas follows Aristotle in his view that time is the measure of movement, but since this view only acknowledges the potential infinite, 
another element was added, namely the actual infinite. These forms of infinity were described in terms of our basic awareness of succession (negatively) and simultaneity (positively). With reference to his Summa Theologica (ST 10.4), Cohn (1960 [1896]:79) summarises the view of Thomas Aquinas as follows: 'In der Ewigkeit giebt es keine Succession, sondern sie existiert ganz und gar zugleich' [In eternity there is no succession, because it exists totally at once]. Thomas Aquinas holds that counting necessarily remains (up to any point) finite - it is impossible to have an actual infinite multiplicity (quoted by Isankrahe 1920:106 'Unde impossibile est, esse multitudinem infinitum actu'; see also p. 108).

Nicholas of Cusa took yet another step by characterising the cosmos as endless and God as infinite in the sense of the actual infinite. Cusanus therefore distinguishes between the absolute (actual) infinity of God and the endlessness of reality. To which he added that of God, as the actual infinite, one can say everything and nothing, for example that he is the largest and the smallest, because in him all oppositions coincide (God is the coincidentia oppositorum - De Docta Ignorantia, 1, 5). Interestingly, Cantor answered Aristotle's second objection to the actual infinite by highlighting some features of omega, the smallest transfinite ordinal number $(\omega)$. Cantor (1962:178-180) has shown that $\omega$ could be presented as both even ( $\omega .2)$ and uneven $(1+\omega .2)$ and, at the same time, (namely when 2 is used as multiplicator) as neither even (2. $\omega)$ nor uneven $(2 \cdot \omega+1)$. This outcome reminds us of Cusanus who saw God as the coincidentia oppositorum (see Hopkins 1985).

Descartes turns the mature conception of ancient Greek philosophy upside down by viewing the infinite as perfect and the finite as imperfect. We can have insight (intelligi) into the infinite, but we cannot grasp (comprehendi) it in a concept. In his explanation in Meditation III, Descartes (1965a:104) equates God with infinity: 'I possess the notion of the infinite before that of the finite, that is, the perception of God before that of myself.' He (Descartes 1965a:111) holds that whatever I see clearly and distinctly must be true, because God cannot deceive me. How do we know that God exists? We know this, because whatever we observe clearly and distinctly must be true, because God would not deceive us. The idea of God as an 'eternal, infinite [immutable], all-knowing, all-powerful' being, contains 'more objective reality than those ideas by which finite substances are represented' (Descartes 1965a:100).

Therefore, because of all the ideas in the human mind, the idea of God is the clearest and most distinct - God must exist. The vicious circle is clear: The existence of God is dependent upon the truth of clear and distinct thinking, while the truth of clear and distinct thinking is dependent upon the (existence of the) non-deceiving God!

\section{From Spinoza to Kant, Maimon, Schelling and Hegel}

Cohn explains that Descartes wanted to differentiate between the infinity of the world and the infinity of God in the following way: he (Cohn 1960 [1896]:147) designates the world as 'indefinite' and God as 'infinitus'. Spinoza gave the next step by considering both the world and God as actually infinite.

In his Critique of Pure Reason (CPR), Kant introduced for the first time, though only once, the expression successive infinite (sukzessivunendlich - Kant 1956 [1787]:552). On the same page, Kant rejects the possibility of an infinite totality - regarding infinitely many divisions of a whole-but in his transcendental dialectic, he smuggled the actual infinite in through the backdoor of the concepts of reason as categories of understanding expanded up to the unconditioned, that is, ideas. These reason ideas are destined to be employed merely in a regulative sense, for if it was done in a constitutive sense, it would have expanded the domain of understanding beyond the limits of experience (Kant 1956 [1787]:647-648, 699-700). It is noteworthy to mention here that the mathematician, David Hilbert (1925:190), calls upon Kant's understanding of the ideas of reason in order to justify his own use of the actual infinite without realising that Kant's appeal - regarding a reason idea transcending experience through which the concrete is expanded into a totality, already made use of the actual infinite.

The philosophical and theological legacy regarding God and infinity, converges into a neat synthesis in the thought of Salomon Maimon. In order to resolve mathematical antinomies, he (Maimon 1790) proposes that understanding can and must be viewed in a twofold perspective:

1. As an absolute [understanding] (not limited by sensibility and its laws).

2. As our understanding, according to its delimitation. (p. 227)

Maimon then continues to reflect on the complete sequence of all natural numbers and concludes that it is not an object that could be given in our intuition, for it is a mere idea through which the successive progression into infinity is viewed as an object. However, reason here contradicts itself 'insofar as it views something as an object that according to its conditions can never be seen as an object' (Maimon 1790:228). In order to resolve this antinomy, one should proceed as follows: An infinite number (because our perception is bound to the form of time), cannot be represented other than as an infinite succession in time (which consequently is not capable of being completed). In the case of an absolute understanding, by contrast, the concept of an infinite number is thought of at once without any passage of time. 'For this reason that which understanding, according to its limitation, views as a mere idea, according to its absolute existence is viewed as a real object' (Maimon 1790:228).

In his Naturphilosophie, Schelling (1968 [1861]:130) made ample use of the actual infinite. He states that infinity as formlessness is not the true infinite, for the latter is only found when it has limited itself and is closed and completed 
('von sich abgeschlossen und vollendet ist'). Later on, he (Schelling 1968 [1861]:199) speaks about an 'infinite present' ('unendlichen Gegenwart') - anticipating Kierkegaard's 'nunc aeternum' [the 'eternal now']. Even with regard to matter, Schelling (1968 [1861]:199) bought into the idea absolute 'gegenwärtiger Unendlichkeit' ['present infinity'].

However, Hegel did not have a proper understanding of the actual infinite (cf. Baer 1932:117), but he still wanted to support it - as can be seen from his critique on 'bad infinity' (cf. Becker 1927:219-220; see also Hegel 1978, I:288). His contribution to the problem of infinity is only indirectly given, namely in his lucid understanding and explanation of the difference between cardinality and ordinality (Hegel 1978, I:260ff.).

When Hegel later on relates finiteness directly to tension (opposition) and contradiction, he does continue something of the later developments of Greek philosophy. However, Hegel continues to struggle with the dialectic of nature (necessity) and freedom, present in modern philosophy since the Renaissance. He believes that in the highest truth the 'resolution of the highest opposition and contradiction is accomplished, for within it the opposition of freedom and necessity, spirit and nature, knowledge and object, law and drive, opposition and contradiction as such, whatever form it may assume, does not any longer have any power' (Hegel 1931:149). Yet, on the previous page, one still reads: 'Freedom is the highest determination of the spirit' (Hegel 1931:148)!

In the meantime, new problems surrounding the mathematical limit concept surfaced and eventually, during the second half of the 19th century, prompted Weierstrass, Dedekind and Cantor to explore the actual infinite in their analysis of the real numbers. In the footsteps of Bolzano, an infinite set was now defined as one that could be mapped in a one-one way to a proper subset of itself (such as correlating the natural numbers $1,2,3$, and so on, with the even numbers - 1 with 2, 2 with 4, 3 with 6 , and so on).

Remark: In following up on our above-mentioned reference to the peculiar nature of the smallest transfinite ordinal number $\omega$ (reminding us of Cusanus and his idea of God as the coincidentia oppositorum), here we may once more refer to the objection of Aristotle, namely that if the actual infinite exists, the whole would not any longer be larger than a part. This objection has now been answered.

From our investigation thus far, it is clear that although the initial context in which the infinite emerged was embedded in a divine principle of Origin, such as water, fire or air, early medieval developments managed to reconcile the idea of infinity with the nature of God. Apparently, the most significant distinction playing an implicit or explicit role in this regard is that between the potential infinite and the actual infinite. It was noted that Kant introduced the expression 'sukzessivunendlich' [the successive infinite].

\section{Arithmetising mathematics on the basis of the actual infinite}

At the same time, the actual infinite appeared to be closely connected to the present, and it was often associated with what is given at once as an infinite whole or totality. The constructivist mathematician, Paul Lorenzen (1972:159), raises the point that within arithmetic itself there is no motif for introducing the actual infinite. He (Lorenzen 1972), however, comprehends the modern set theoretic approach very well while explaining it strikingly as follows:

One rather imagines the real numbers as all of them at once [auf einmal] really at hand, and even every real number as an infinite decimal fraction is also imagined as if the infinitely many digits exist all at once. (p. 163)

This explanation captures two key features of the actual infinite: first, the representation of a multiplicity of numbers at once; and second, as an infinite totality (Ganzheit/ Gesamtheit). Paul Bernays (1976) connects the idea of being given at once as a whole with the nature of (spatial) continuity. According to him, the continuum is a geometric idea which is expressed by analysis in an arithmetical language. It is also the totality character, belonging to the geometrical representation of the continuum that resists a complete arithmetisation of the continuum (Bernays 1976:74). In opposition to the arithmetising monism in mathematics, the idea of the continuum is originally a geometric idea (Bernays 1976:188). Lorenzen (1972:159) also points out that the expansion of our number concept by means of actual infinity still reminds us of the fact that the modern concept of a real number is built upon the actual infinite which reveals its descent from geometry.

At this point, we may introduce alternative expressions for the potential infinite and the actual infinite, because these traditional designations lack intuitive clarity. We substitute the potential infinite with the successive infinite and the actual infinite with the at once infinite. These two expressions also capture their connection with number and space: firstly, the most primitive and original meaning of the infinite is given in the time order of succession of the natural numbers; and secondly, the idea of an infinite multiplicity given at once as a whole or totality, imitates two crucial spatial features, namely the spatial time order of simultaneity and the spatial wholeparts relation.

\section{Infinity and God}

Meschkowski (1972) provides us with a comprehensive understanding of the key mathematical and theological elements in Cantor's thought. He (Meschkowski 1967:112) explains that Cantor distinguishes between the successive infinite, the at once infinite and the 'Absolute Infinite'. The expression absolute infinite differs from the successive infinite and the at once infinite, because it refers to God (Meskowski 1967:112-113). 
It is remarkable that Hermann Weyl, the exceptional student of David Hilbert, left the school of axiomatic formalism for the intuitionism of Brouwer who rejects the actual infinite (at once infinite - also designated as the 'completed infinite'). With the actual infinite out of the way, Weyl (1966) decided to accommodate God in its place. This entails that he (Weyl 1966:89) accepts the successive infinite and even calls mathematics the 'science of the infinite' on condition that mathematics avoid the at once infinite. According to Weyl (1932:84), the 'completed infinite' can only be 'represented in symbols' - and God is the completed infinite.

\section{Theology and the infinity of God}

The Bible does not explicitly attribute infinity to God, although the theological tradition derived God's infinity from his omnipresence and eternity alongside attributes such as immutability and timelessness (Leftow 2005:62ff.). In line with the historical contours outlined, the idea of eternity also entered the theological domain in the form of two apparently opposing notions: eternity as an endless period of time, and eternity as timelessness. These notions may be related to the so-called Platonic and Aristotelian traditions, but actually should be connected with the two conceptions of infinity operative in the history of mathematics and theology.

When mention is made of God's infinity in a theological context, the presupposition is that infinity in its original meaning, eminently, belongs to God with the implication that the mathematical understanding of infinity is derived from the theological understanding of God's infinity. Yet, the primitive awareness of one, another one and so on, without an end, primarily derives from the numerical aspect of reality. The meaning of space reveals our awareness of simultaneity, of what is given at once. Leibniz, for example, juxtaposes time as 'an order of successions', with space, as 'an order of coexistences' (Leibniz 1965:199). Kant (1956 [1787]:219) distinguishes three modes of time: persistence, succession and simultaneity (Beharrlichkeit, Folge und Zugleichsein). Bertrand Russell (1956:299) aptly remarks that 'progressions are the very essence of discreteness'.

Oscar Cullmann (1949) posits the following requirement in

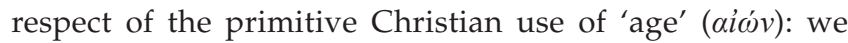
'must free ourselves completely from all philosophical concepts of time and eternity'. There are two elements behind the understanding of eternity: firstly, eternity is an endless duration of time ('Eternity is the endless succession of the ages'); and secondly, eternity as the timeless present (Parmenides; Diels \& Kranz 1959-1960 B. Fragment 8:3-6; Plato; Plotinus - En. III, 7; Kierkegaard's nunc aeternum).

Wittgenstein $(1966: 147,6.4311)$ uses this legacy in his remark: 'If we take eternity to mean not infinite temporal duration but timelessness, then eternal life belongs to those who live in the present.' Cullmann (1949:63) points out that Karl Barth struggles with the 'temporal quality of eternity', that is, with the intrusion of the 'Platonic conception of timeless eternity', and on the same page, he continues: 'Primitive Christianity knows nothing of a timeless God.'

The remarkable fact, however, is that the understanding of eternity depends upon diverse views of infinity. If one merely accepts the successive infinite, eternity will mean an endless duration of time; thus, exploring the first two modes of time distinguished by Kant (duration and succession). Nevertheless, when eternity is seen as timelessness, the third mode of time, distinguished by Kant, prevails: simultaneity naturally associated with the at once infinite.

\section{A theo-ontological circle}

By not recognising the aspects of number and space behind these two views of eternity, a neat theo-ontological circle emerges. Firstly, infinity is lifted from its cosmic 'place' 'seated' within the aspectual meaning of number or, as it is in the case of the at once infinite, in the way in which the meaning of number is deepened by imitating the spatial meaning of simultaneity and its correlate: the spatial wholeparts relation. Secondly, this 'transposed' meaning of number is elevated to God before it is finally 'copied back' to creation. Once the assumption is made that it originally belongs to God, infinity can only be reintroduced within the domain of number by taking it over from theology.

Alternatively, a theologian should primarily give an account of the fundamental concepts (and ideas) employed by mathematicians and theologians. This philosophical issue pertains to the phenomenon that different scientific disciplines frequently use scientific terms in a distinct way. These terms are known as the analogical basic concepts of the disciplines.

For example, no one can deny that both mathematicians and theologians use numerical terms such as the numerals one, two and three. The underlying philosophical issue leads to the following question: Are these notions originally (that is, in a structural-ontic sense) numerical notions that are used analogically within a different (faith) context when theologians say that there is but 'one' God, or when they speak of God's 'tri-unity'?

We have noted that only when this numerical intuition is deepened by our spatial awareness of at once (simultaneity), we can consider any infinitely proceeding sequence as if all its elements are given simultaneously, that is, as a 'completed totality'. Just remember the example of the real numbers given by Lorenzen. Without an insight into the meaning of number and space, it would be impossible to account for these two basic manifestations of infinity. The at once infinite imitates the wholeness of the spatial whole-parts relation the totality character of continuity as Bernays characterised it earlier. In a different context, Russell (1956:70) criticises Bolzano for not distinguishing the 'many from the whole which they form'. 


\section{Is infinity brought into mathematics on a Christian theological foundation?}

Once the ontic status of number, space and infinity has been acknowledged, it sounds strange to hear Chase (1996:209) asking: 'Could infinities such as a completed totality be brought into mathematics without a Christian theological foundation?' Instead of the closing phrase 'without a Christian theological foundation?', one could have expected an alternative phrase: 'without an understanding of the uniqueness and mutual coherence of the (ontic) aspects of number and space?'

Yet, Chase (1996:209) proceeds in the opposite direction: 'At the very least, some idea of God standing outside of our experience must have been necessary, since apart from God we have no experience of the infinite.' He (Chase 1996:209-210) also acknowledges that some medieval Scholastics and some 19th century mathematicians (such as Cantor) 'believed in an actual mathematical infinity, based on God's infinity'.

Chase's closing remark is still theo-ontologically informed and it misses the decisive point. He has precluded the option of acknowledging infinity in both its forms as 'mathematical' in nature, that is, as numerical and numerically deepened analogies operative within the theological universe of discourse. By doing this, the implicit dualism presupposed in his argument could be reversed. Instead of supposing that the notion of 'infinities such as a completed totality' originally is a theological idea that is completely foreign and external to mathematics, one would then much rather acknowledge that within the structural nature and interrelationships between number and space, we first of all encounter the basic notion of infinity - which secondarily could be reflected within the structure of the certitudinal aspect in an analogical way. By not tracing the notion of infinity back to its original 'modal seat', it can only serve as a notion brought into mathematics 'from the outside', that is, as something 'purely' theological that can only bear upon the field of investigation of mathematics in the second place.

However, by recognising the (deepened) numerical seat of the notion of infinity, one should rather start from the assumption that theologians could only use notions of infinity as mathematical analogies in their theological argumentation - or, as will be argued below, as modal terms employed in concept-transcending ways.

For example, Chase does not even enter into a discussion of the notion of infinity as it is traditionally employed in Christian theology, for then, at least, he might have taken note of the fact that the Bible nowhere explicitly attributes infinity to God. Theologians traditionally extrapolate God's infinity from his omnipresence and eternity.

\section{The important distinction between conceptual knowledge and concept-transcending knowledge (idea-knowledge)}

When the biblical mode of speech explores modal aspects as points of entry, it does so in a concept-transcending way. Of course, it does not exclude the aspects of number and space. The most basic biblical idea statement about God is that God is unique - there is but ONE God. This idea of God's uniqueness stretches the meaning of the numerical term one beyond the limits of the numerical aspect. For this reason, one cannot acquire a concept of God, because concepts are constituted by universal traits capturing the universal conditions for whatever is subject to those conditions. If it was possible to form a concept of God, there would have been an order for 'being a god' and, consequently, many instances of God - contradicting the biblical claim that there is but ONE God. Moreover, then God would have been subjected to a law order like other creatures, eliminating God's transcendence.

Likewise, we are accustomed to a spatial unity and multiplicity, for example when we understand what a triangle is all about. A triangle is normally subsumed under the concept of a polygon and is supposed to be constituted by three corners (vertices) and three straight line-segments as sides so that the interior of the triangle, which is that part of a plane that is enclosed by the triangle, correlates with its outside (its exterior). The term triangle literally speaks of a 'three-in-one' - with a clear numerical and spatial connotation. Yet, we can stretch the use of these numericospatial elements beyond the boundaries of the spatial aspect of reality, namely when we deduce from Scriptures the idea of the triune God (the Bible does not use this expression as such).

Therefore, when one asks if this does not project onto God categories that are modal in nature, the actual situation is turned upside down. Alternatively, one should rather consider instances of aspectual (modal) terms stretched beyond the limits of the aspects in which they have their original modal seat.

For example, a 'stretched' employment of our kinematic intuition provides us with the idea of continued being - a concept-transcending use of the core kinematic meaning of rectilinear (uniform) movement. The first manifestation of such a concept-transcending use of the meaning of the kinematic aspect is given in our idea of identity. When we stretch this idea beyond creation, we arrive at the eternity of God - compare Exodus 3:14: 'I am who I am.'

The basic concept of infinity is given in the (purely arithmetical) understanding of endlessness - what Kant calls the successive infinite. We encounter the deepened idea of infinity when the numerical meaning of succession is disclosed by the spatial 
meaning of simultaneity (at once) - hence the idea of the at once infinite.

Both these notions of the infinite may point beyond creation to God. Then we may want to acknowledge both the contribution of the numerical aspect (the love, power, etc. of God 'has no end') and that of the spatially deepened contribution of the at once infinite - God's omnipresence embraces the entire universe at once. This approach avoids the dialectical opposition which is normally attached to these two options: eternity as an endless time, and eternity as timelessness. Applying the distinction between conceptual knowledge and concept-transcending knowledge eliminates this false opposition. What is needed is an understanding of the uniqueness and mutual coherence of number and space, and the fact that the meaning of both these aspects (and their interrelations) could be employed (also theologically regarding the infinity of God) in concepttranscending ways.

\section{Acknowledgements Competing interests}

The author declares that he has no financial or personal relationship(s) which may have inappropriately influenced him in writing this article.

\section{References}

Baer, R., 1932, 'Hegel und die Mathematik', in B. Wiegerma (Hrsg.), Verhandlung des 2. Hegel Kongresse vom 18-21 Okt, J.C.B. Mohr, Tübingen.

Becker, O., 1927, Mathematische Existenz. Untersuchungen zur Logik und Ontologie mathematischer Phänomene, Max Niemeyer Verlag, Tübingen.

Bernays, P., 1976, Abhandlungen zur Philosophie der Mathematik, Wissenschaftliche Buchgesellschaft, Darmstadt.

Cantor, G., 1962, Gesammelte Abhandlungen Mathematischen und Philosophischen Inhalts, Oldenburg Verlag, Hildesheim.

Chase, G.B., 1996, 'How has Christian Theology furthered Mathematics?', in J.M. van der Meer (ed.), Facets of Faith and Science. The Role of Beliefs in Mathematics and the Natural Sciences: An Augustinian perspective, vol. 2, pp. 193-216, University of America Press, New York.

Cohn, J., 1960 [1896], Geschichte des Unendlichkeitsproblems im abendländischen Denken bis Kant, Unveränderter fotomechanischer Nachdruck, Wissenschaftliche Buchgesellschaft, Darmstadt.

Cullmann, O., 1949, Christ and time: The primitive Christian conception of time and history, The Westminister Press, Philadelphia, PA.

Descartes, R., 1965a, A discourse on method, meditations and principles, transl. J. Veitch, introduced A.D. Lindsay, Everyman's Library, London.

Descartes, R., 1965b, 'The principles of philosophy, in R. Descartes (ed.) A discourse on method, meditations and principles, transl. J. Veitch, introduced A.D. Lindsay, pp. 147-228, Everyman's Library, London.
Diels, H. \& Kranz, W., 1959-1960, Die Fragmente der Vorsokratiker, vols. 1-3, Weidmannsche Verlagsbuchhandlung, Berlin.

Dooyeweerd, H., 2013, Reformation and Scholasticism in Philosophy, ed. D.F.M. Strauss, Paideia Press, Grand Rapids, MI. (The collected works of Herman Dooyeweerd, 5/2)

Guthrie, W.K.C., 1980, A history of Greek philosophy, Cambridge University Press, Cambridge. (The Presocratic tradition from Parmenides to Democritus, 2).

Happ, H., 1971, Hylē, Studien zum aristotelischen Materie-Begriff, De Gruyter, Berlin.

Hasse, H. \& Scholz, H., 1928, 'Die Grundlagenkrisis der Grieschischen Mathematik', Kant Studien 33(1-2), 4-34.

Hegel, G.W.F., 1931, 'Die Idee und das Ideal', in. G. Lasson (Hrsg.), Sämtliche Werke, Band 10a, Felix Meiner, Leipzig.

Hegel, G.W.F., 1978, Wissenschaft der Logik, vol. I, Suhrkamp, Frankfurt am Main. (Originally published as part of the Collected Works of Hegel, 1832-1845).

Hilbert, D., 1925, 'Über das Unendliche', Mathematische Annalen 95, 161-190. https://doi.org/10.1007/BF01206605

Hilbert, D. 1970. Gesammelte Abhandlungen, Vol.3, Second Edition, Berlin: Verlag Springer.

Hopkins, J., 1985, 'Nicholas of Cusa' in, On learned ignorance, 2nd edn., Banning Press, Minneapolis, MN.

Isankrahe, C., 1920, Untersuchungen über das Endliche und das Unendliche, A. Marcus \& E. Webers Verlag, Bonn.

Kant, I., 1956 [1787], Kritik der reinen Vernunft, 2nd edn., Felix Meiner Verlag, Hamburg.

Krämer, H.J., 1969, 'Kramer EPEKEINA TES OUSIAS, Zu Platon, Politeia 509 B', Archiv fur Geschichte der Philosophy 51 (1), 1-30.

Leftow, B., 2005, 'Eternity and immutability', in W.E. Mann, (ed), The Blackwell Guide to the Philosophy of Religion, pp. 48-77, Blackwell Publishing, Oxford.

Leibniz, G.W.H., 1965, 'Correspondence with Clarke', in G.H.R. Parkinson (ed.), Leibniz philosophical writings, transl. M. Morris, pp. 198-203, Everyman's Library, London.

Lorenzen, P., 1972, 'Methodisches Denken', in H. Meschkowski (ed.), Grundlagen der Mathematik, pp. 157-178, Wissenschaftliche Buchgesellschaft, Darmstadt.

Lorenzen, P., 1976, 'Zur Definition der vier fundamentalen Meßgrößen', Philosophia Naturalis 16, 1-9.

Maimon, S., 1790, Versuch über die Tranzendentalphilosophie; mit einem Anhang über die symbolische Erkenntnis und Anmerkungen, Wissenschaftliche Buchgesellschaft, Darmstadt.

Meschkowski, H., 1967, Problemen des Unendlichen, Vieweg, Braunschweig.

Meschkowski, H., 1972, Grundlagen der Mathematik, Wissenschaftliche Buchgesellschaft, Darmstadt.

Mühlenberg, E., 1966, Die Unendlichkeit Gottes bei Gregor von Nyssa. Gregors Kritik am Gottesbegriff der klassischen Metaphysik, Vandenhoeck\& Ruprecht, Göttingen.

Russell, B., 1956, The principles of Mathematics, 7th edn., George Allen \& Unwin, London.

Schelling, F.W.J., 1968 [1861], 'Schriften von 1806-1813', vol. 4, Wissenschaftlichen Buchgesellschaft, Darmstadt.

Solmsen, F., 1962, 'Anaximander's infinite: Traces and influences', Archiv für Geschichte der Philosophie De Gruyter 44(1), 109-131.

Sweeney, L., 1972, Infinity in the Presocratics. A bibliographical and philosophical study, Martinus Nijhof, The Hague.

Von Weizsäcker, C.F., 1972, Voraussetzungen des naturwissenschaftlichen Denkens, Herderbucherei, Band 415, Freiburg.

Weyl, H., 1932, 'Infinity', in H. Weyl (ed), The Open World, pp. 57-84, Yale University Press, New Haven.

Weyl, H., 1966, Philosophie der Mathematik und Naturwissenschaft, 3rd rev., expanded edn., R. Oldenburg, Vienna.

Wittgenstein, L., 1966, Tractatus Logico-Philosophicus, 3rd edn., Routledge \& Kegan Paul, London. 